\title{
DO ISLAMIC EQUITY STYLE INDICES CONTAIN ECONOMIC INFORMATION? ${ }^{1}$
}

\author{
Shahrin Saaid Shaharuddin ${ }^{1}$, Wee-Yeap Lau ${ }^{2}$ and Tien-Ming Yip ${ }^{3}$ \\ ${ }^{1}$ Faculty of Business and Accountancy, University of Malaya, Malaysia, shahrin@um.edu.my \\ ${ }^{2}$ Faculty of Economics and Administration, University of Malaya, Malaysia, wylau@um.edu.my \\ ${ }^{3}$ Faculty of Economics and Administration, University of Malaya, Malaysia, yiptienming@um.edu.my
}

\begin{abstract}
This study aims to investigate whether the Islamic equity style index contains economic information which is useful for investors and financial practitioners. The study fills the gap in the previous literature by investigating the relationship between Islamic equity style indices and macroeconomic variables. Using a Vector Autoregressive (VAR) model with monthly data from June 2006 to May 2017, our results show that first, there is unidirectional flow of information from Large Growth (LG) to the Leading Economic Indicator (LEI); second, Large Growth (LG) Granger-causes the Kuala Lumpur Composite Index (KLCI); third, Large Value (LV) also Granger-causes KLCI. A robustness check with an Augmented VAR model obtained similar results to the shortrun model. Our results imply that equity style indices have prior information which is faster than LEI and KLCI. This knowledge is certainly useful for fund managers when designing Shariah-compliant portfolio investments. For policymakers, Islamic equity style indices are useful for predicting the direction of other macroeconomic variables such as business cycles, and hence help to predict the future direction and turning points in the economy.
\end{abstract}

Keywords: Islamic equity style index, Leading economic indicator, Macroeconomic variables.

JEL Classification: C53; E32; G11.

$\begin{array}{ll}\text { Article history: } & \\ \text { Received } & \text { : October 17, } 2019 \\ \text { Revised } & \text { : August 18, 2020 } \\ \text { Accepted } & \text { : August 27, 2020 } \\ \text { Available online } & \text { : November 25, } 2020\end{array}$

https://doi.org/10.21098/jimf.v6i4.1182

1 This work was supported by the UM-INCEIF Research [grant number MO006-2017]. 


\section{INTRODUCTION}

\subsection{Background}

Numerous studies have been written to predict the future direction of economic trends in emerging countries, yet there has been no previous work on how Islamic equity style factors have information content that precedes macroeconomic variables. This study, therefore, is beneficial as it attempts to unravel the relationship between Islamic equity style indices and their ability to predict future economic performance.

Studies in the area of stock market indices have previously been limited to the area of conventional indices, focusing mainly on evaluating their ability to forecast future states of the economy. In contrast, few studies have analysed Islamic equity style indices, especially ones which link Islamic stock indices to macroeconomic variables.

Furthermore, a risk-based explanation of Islamic Fama and French factors and their forecasting abilities would be useful for investment managers when developing trading strategies. It has long been argued that High Minus Low (HML) and Small Minus Big (SMB) portfolios generate excess returns for investors. Nonetheless, little has been done to evaluate the effectiveness of Islamic growth and value factors based on stocks selected from emerging market economies, together with their predictive qualities.

The Islamic capital market has become increasingly prominent in Malaysia, since the inception of the Kuala Lumpur Shariah Index on 17 April 1999 (Baity \& Ahmad, 2008). Studies have been conducted to evaluate the Fama and French (1992) stylised facts, most notably the analyses made by Liew and Vassalou (1999) and Vassalou (2003). These studies found that style indices based on conventional stock market indices were promising, and that they contained information content which led to other economic indicators. Hence, similar efforts should be made to develop Islamic equity style indices from the Shariah-based index in Bursa Malaysia.

Besides, the utilisation of equity style indices as a benchmark in investment management has gained more momentum in recent times. It has been hypothesised that if the Fama and French variables can be used as a reliable benchmark, they should be able to transmit information to the rest of the economy efficiently. Based on this assumption, this study will focus on the Islamic equity style indices, which are tested against macroeconomic variables using the Vector Autoregression model (VAR). Previous findings by Liew and Vassalou (1999), Lau et al. (2005), Tan and Lau (2013) and Lau and Lee (2015) have shown the existence of economic content in equity style indices.

\subsection{Objective}

The study first aims to fill the gap by providing a theoretical framework to link stock market indices to other economic indicators and to examine the information transmission capabilities of Islamic equity style indices. It also intends to provide empirical evidence to support the missing link between equity style indices, especially the value and growth styles, and macroeconomic indicators. 
The study has been made possible by the creation of a new set of Islamic equity style indices based on the stocks listed on the FTSE EMAS Shariah index by Shaharuddin, Lau and Ahmad (2017b). This set of new indices was created based on the methods proposed by the Russell Co., and we can now test the efficacy of the indices using contemporary econometric methods. In this paper, the large growth (LG) and large value (LV) indices were selected for analysis and to evaluate their information transmission capabilities.

The remainder of the paper is structured as follows: Section 2 discusses relevant studies, while Section 3 explains the empirical method used. Section 4 discusses the data and variables, and is followed by discussion of the results. The final section presents the conclusion and recommendations.

\section{LITERATURE REVIEW}

\subsection{Background Theory}

The efficient market hypothesis (EMH) postulates that competition among profitmaximising investors in the stock market will ensure that current stock prices are formulated based on all the relevant information known about changes in the macroeconomic variables. Therefore, these variables, such as inflation, money supply and exchange rates, are found to be the determinants of stock prices (Fama, 1981; Chen et al., 1986; Mayasami \& Sims, 2002).

Studies on the causality between conventional stock prices and macroeconomic indicators have been conducted extensively in both developed and developing countries (Hashemzadeh \& Taylor, 1988; Mookerjee \& Yu, 1997; Kwon \& Shin, 1999; Ibrahim \& Aziz, 2003; Gan et al., 2006; Acikalin et al., 2008; Semra \& Ayhan, 2010; Ahmed et al., 2017; Khandelwal, 2018; Camilleri, Scicluna, \& Bai, 2019). By and large, the empirical studies have shown that there exists an information flow between conventional stock prices and some macroeconomic variables, such as GDP, foreign exchange, the current account balance, interest rate, inflation rate, industrial production index, money supply and foreign reserves.

\subsubsection{Information Transmission Capabilities of Macroeconomic Variables}

The research conducted in the area of forecasting future economic conditions has mainly revolved around the use of macroeconomic variables and their ability to predict the health of the economy. However, following the findings by Fama and French $(1992,1993)$, researchers found the evidence that size and value factors are useful in forecasting the trend of economy. The role of macroeconomic factors can be traced back to the seminal work of Burns and Mitchell (1945). They advocated the use of economic indicators which predict the future trend of economy, whether there will be economic growth or recession.

However, the indicators proposed by Burns and Mitchell (1945) were later revised by Stock and Watson (1989) in the form of leading and coincident economic indices based on contemporary tools of time series econometrics. Stock and Watson (1989) developed a probability model, which gave rise to the CEI and LEI indices. Their study went beyond developing the LEI and CEI by including a recession index, intended to provide signals to suggest the possibility of an economic downturn. 
Consequently, Diebold et al. (1991) continued the work of Stock and Watson (1989) by testing the composite leading economic indicators used to forecast future economic activity. When tested using real-time forecasting equations, the composite leading index was not able to improve forecasting performance. Nonetheless, the results need to be interpreted carefully, as experienced investors and users of this index can use their knowledge to interpret it based on personal methods. This suggests that the composite leading index does indeed possess forecasting abilities. Furthermore, Diebold et al. (1991) also suggested that the components that were used to develop the composite leading index needed to be correctly selected and that there may have been "mistakes" in their selection, leading to the inexplicable results.

\subsubsection{Information Transmission Capabilities of Stylized Indices}

The findings by Burns and Mitchell (1945) became a catalyst for future research in the area of leading economic indicators and their predictive qualities. An interesting study by Liew and Vassalou (1999), which was predicated on the research work conducted by Fama and French (1992), supported the argument that the Fama and French factors (i.e. "High Minus Low" (HML) and "Small Minus Big" (SMB)) contained economic information which preceded future GDP growth. With the benefit of data provided by ten developed international markets, it was found that the HML and SMB factors were better at explaining future GDP growth compared to the Winners Minus Losers (WML) factor.

With the theoretical underpinnings firmly established, research studies began to emerge in areas relating to the development of composite and leading economic indicators. Diebold and Rudebusch (1996), for instance, found that the dynamic factor model and nonlinear regime-switching models of macroeconomic variables was more useful in analysing business-cycle data. The evidence from their study indicates that the business community is concerned with turning points, and that small forecast improvement as a result of a regime switch may lead to a significant effect in terms of company profits.

Diebold et al.'s (1991) study was further tested by Hamilton (2011), who argued that there were difficulties in predicting economic downturns in real-time. He further suggested that this was due to the ability of economic participants to predict a recession, the effect of data revisions, and the fact that the relationship between crucial variable changes over time. Nonetheless, Ferrara and van Dijk (2014) recommended that investors and policymakers should not only be concerned about point forecasts, or the signalling qualities of the chosen macroeconomic variable, but also about the effects on their decision making as a result of the various possible effects that need to be considered, based on the results of probability distribution studies.

Banerjee and Marcellino (2006) analysed the merits of alternative approaches to forecasting inflation and GDP growth in the United States. Interestingly, their findings provided guidance on the best leading indicators that should be selected. Efforts to find the most suitable leading economic indicators were also made by Babecky et al. (2013). 
Subsequently, Frankel and Saravelos (2012) found that it was essential to specify economic variables which could accurately describe the 2008 and 2009 financial crises. They demonstrated that the level of central bank reserves could be used as a significantly consistent leading indicator which would lead financial crises.

The link between equity style indices and leading economic indicators in emerging market economies such as Malaysia was studied by Lau and Lee (2015). In their paper, the evidence suggested that an equity style index is better at transmitting economic information than a stock market sectoral index. Furthermore, it was shown that growth style indices contained economic information that precedes the leading economic index (Tan \& Lau, 2013). The results of their study are promising, and seem to support the hypothesis of informational content within the Fama and French factors.

\subsection{Previous Studies}

\subsubsection{Links Between Islamic and Conventional Stock Markets}

Studies on the dynamic links between Islamic stock indices and macroeconomic variables are somewhat limited. In one example, Ajmi et al. (2014) used linear and nonlinear Granger causality tests to investigate the links between Islamic and conventional stock markets, and between Islamic stock markets and several global economic and financial shocks. The results show that Islamic stock markets strongly influence their conventional counterparts. Moreover, causality also runs from Islamic stock markets to financial and risk factors.

\subsubsection{Stock Market Index and Informational Efficiency}

However, subsequent studies showed that there was information inefficiency in Islamic stock indices. As such, Wahyudi and Sani (2014) employed the Toda Yamamoto causality test to ascertain the relationship between macroeconomic variables and the Islamic financial market. Based on monthly data from 2002 to 2011, their study found that exchange rates and the VIX index predicted the movement of the Islamic capital market index (JII). Similarly, Kumar and Sahu (2017) found robust unidirectional causality from money supply and exchange rates to the Dow Jones Islamic India market index.

In the case of Malaysia, Yahya et al. (2012) found that there was information inefficiency in Islamic stock indices, in which the FTSE Bursa Malaysia Emas Shariah Index (a proxy of Islamic stock index) was found to be preceded by the industrial production index and Islamic interbank rate. Using the same proxy, Hussin et al. (2012) documented that global oil prices were vital in determining the movement of the Islamic stock index. In a later study, Hussin et al. (2013) examined the links between Islamic stock index, strategic commodities (oil and gold prices) and macroeconomic variables. Using data from January 2007 to December 2011 and the FTSE Bursa Malaysia Emas Shariah Index (a proxy of Islamic stock index), the study found that there was causality between Islamic stock returns and economic growth, Islamic interbank rates and crude oil prices. 
The newly-developed Islamic equity style indices provide new impetus to study the information transmission capabilities of style indices vis-à-vis macroeconomic variables. A study by Liew and Vassalou (1999) provides evidence which supports the argument that the Fama and French-style indices do indeed have information content which precedes macroeconomic variables and can therefore be used to predict future economic conditions.

Nonetheless, there has also been a significant amount of academic research work conducted on the application of stock market indices to market efficiency and the study of portfolio diversification benefits. With regard to market efficiency, research by Fama (1970) to establish the random walk proposition of the efficient market hypothesis provided investors and financial market researchers with a theoretical base for them to understand financial markets and portfolio management better. According to Fama, if there is no autocorrelation between financial markets, they are efficient and not integrated.

This argument was contradicted by various other studies, including that of Lo and Mackinlay (1987), who argued that a random walk did not exist. Similarly, De Bondt and Thaler (1985) provided evidence to suggest that markets were not efficient and that market psychology played a role in causing stock prices to vary from their expected price.

Studies on emerging markets and Islamic stock markets have also been conducted by Khalichi et al. (2014) and Baity and Ahmad (2008), who provide evidence to suggest that there is a degree of cointegration between the Islamic stock market indices and macroeconomic indices. As a result, the cointegration would suggest that there is a violation of the random walk theory suggested by Fama (1970) and that in fact markets are not efficient.

The diversification benefits of stock market indices have been argued to exist when markets are less efficient. The example of the Kuala Lumpur Shariah Index (KLSI) and its unidirectional return volatility transmission capabilities concerning the Jakarta Islamic indices would suggest that there are fewer diversification benefits between the two stock markets (Wahyudi \& Sani, 2014).

\subsection{Conceptual Framework}

As mentioned above, the Islamic growth style and value style indices are used as the equity style indices in this study. Since the equity style index has economic content, it is hypothesised that:

Hypothesis 1: There will be an information flow between the Islamic equity style index and leading economic indicators.

Hypothesis 2: There will be an information flow between the Islamic equity style index and the stock market index.

As discussed above, the Islamic equity style index is a refinement of the Islamic stock market index. Hence, the information content of the movement of growth and stock values should precede the movement of other indicators. Therefore, Hypothesis 1 is strong. 
Theoretically, most growth stocks are large capitalisation stocks similar to the component stocks in a broad market index such as the Kuala Lumpur Composite Index. Therefore, Hypothesis 2 intends to confirm whether an information flow exists between the Islamic equity style index and KLCI.

\section{METHODOLOGY}

\subsection{Data}

Based on the Islamic equity style index from June 2006 to May 2017, and as discussed in Shaharuddin, Lau, and Ahmad (2017a, 2017b), the macroeconomic indicators were chosen because they had good economic indicator characteristics. For the purposes of this research, these characteristics needed to include relevance, reliability and accessibility, and be easy to understand (Sustainability Indicators 101, 2010). The variables used are summarised in Table 1; their choice was based on the discussion in section 2.3 of the theoretical framework.

Table 1.

List of Variables

\begin{tabular}{|c|c|c|c|}
\hline Variable & Description & Unit of measurement & Source \\
\hline LG & $\begin{array}{l}\text { Large Growth Islamic } \\
\text { Equity Style Indices }\end{array}$ & Base Value (100) & Author's construction \\
\hline LV & $\begin{array}{l}\text { Large Value Islamic Equity } \\
\text { Style Indices }\end{array}$ & Base Value (100) & Author's construction \\
\hline LEI & Leading Economic Indicator & Base Value (100) & $\begin{array}{l}\text { Department of Statistics, } \\
\text { Malaysia }\end{array}$ \\
\hline CEI & $\begin{array}{l}\text { Coincident Economic } \\
\text { Indicator }\end{array}$ & Base Value (100) & $\begin{array}{l}\text { Department of Statistics, } \\
\text { Malaysia }\end{array}$ \\
\hline KLCI & $\begin{array}{l}\text { Kuala Lumpur Composite } \\
\text { Index }\end{array}$ & Base Value (100) & $\begin{array}{l}\text { Kuala Lumpur Stock } \\
\text { Exchange }\end{array}$ \\
\hline Industrial & $\begin{array}{l}\text { Bursa Malaysia Industrial } \\
\text { Index }\end{array}$ & Base Value (100) & $\begin{array}{l}\text { Kuala Lumpur Stock } \\
\text { Exchange }\end{array}$ \\
\hline
\end{tabular}

\subsection{Construction of the Equity Style Indices}

The first step in developing the Islamic equity style indices in Malaysia was to categorise companies on the FTSE EMAS Shariah index according to growth, value and blend shares. The shares were selected based on companies listed on the Shariah Index by the Shariah Advisory Council of the Securities Commission of Malaysia (SC). The list of Shariah-compliant companies on the KLSE is revised and reported twice a year. The list was then compiled and matched with the list of companies in the FTSE EMAS Shariah index. The companies selected were then divided based on the top 30 companies (large companies).

Once the list of Shariah-compliant companies has been collected, the methodology for sorting shares, according to growth and value was performed by taking the following steps.

To classify and construct an index based on value and growth shares, the Priceto-Book (P/B) ratio was employed; the process is described below (Fabozzi, 1998): 
Step 1: Select a universe of shares.

Step 2: Calculate the total market capitalisation of all the shares in the universe.

Step 3: Using the variables for classification, develop a score for each share, with the highest score being value.

Step 4: Sort the shares from the highest score to the lowest.

Step 5: Calculate the capitalisation-weighted median of the scores.

Step 6: Select the shares with scores above the capitalisation-weighted median calculated in Step 5 and classify them as value shares.

Step 7: Classify the remaining shares in the universe as growth shares.

The method employed was in part similar to that proposed by Fabozzi (1998) and has been used by the index providers such as the Russell Co. and Morningstar in order to develop equity style indices. More details of the index construction can be found in Shaharuddin et al. (2017b)

\subsection{Unit Root and Stationarity Test}

\subsubsection{Phillips-Perron (PP) Test}

The unit root rest was conducted to ensure the stationarity of the variables being tested. For this study, the Phillips-Perron unit root test was preferred for the small sample study, following Hallam and Zanoli, and Obben.

The PP test equation was as below:-

$$
\Delta y_{t}=\mu+\beta t+\gamma y_{t-1}+\varepsilon_{t}
$$

where $\mu$ is a constant and $\beta$ denotes the coefficient on a time trend, while $p$ is the lag order of the autoregressive function and $\varepsilon$ is the error term. The test for stationarity can be further explained based on the following hypothesis:

Ho: $y=0$ (The series needs to be differenced in order to make it stationary);

$\mathrm{H}_{1}: \mathrm{y}<0$ (The series is stationary and does not need be differenced)

\subsubsection{Kwiatkowski-Phillips-Schmidt-Shin (KPSS) test}

However, the power of PP tests is low if the process is stationary, but with a root close to the non-stationary boundary. One way to circumvent this is to use a stationary test, for example the Kwiatkowski-Phillips-Schmidt-Shin (KPSS) test.

To further explain the KPSS test, it can be argued that KPSS is another unit root test with time trend $t$, where:

$$
y_{t}=\mu+\beta t+\varphi \sum_{i=1}^{t} \varepsilon_{t-1}+u_{t}
$$

which is tested under $\mathrm{H}_{0:} \phi=0$ (the trend is stationary) against $\mathrm{H}_{0:} \phi \neq 0$ (the trend is not stationary), where $\mu$ is constant, $u_{t}$ is a stationary process and the past error $\varepsilon_{\mathrm{t}-1} \sim$ i.i.d $(0,1)$. The test statistic is based on the LM statistic, where $\mathrm{H}_{\mathrm{o}}$ is rejected if computed LM $>$ KPSS asymptotic critical value, and the series $y_{t}$ is regarded as stationary. 


\subsection{VAR model}

For this study, the variables listed in Table 1 were used. Due to the short-run nature of data, the Vector Autoregressive (VAR) model is more suitable other models. It is based on the Sims (1980) model, of which it takes the form of multiple simultaneous equations, and the endogenous variables in each equation form a regression with the lagged values of all the endogenous variables. This is done in order to estimate the dynamic relationships between all the endogenous variables.

Both long-run and short-run restrictions to be explained by economic considerations. As a result, the VAR model can be used to describe the impact of factors influencing the dependent variable based on the indices chosen for the study.

The mathematical equation of a general VAR (p) model is as follows:

$$
Y_{t}=+\emptyset_{1} Y_{t-1}+\emptyset_{2} \Delta Y_{t-2}+\ldots+\emptyset_{p} Y_{t-p}+\mu_{t}
$$

where $Y_{t}$ is a $K \times 1$ vector of variables; $\Phi i$ is a $K x \mathrm{~K}$ coefficient matrix; and $u_{t}$ is a $\mathrm{K} \times 1$ vector of stochastic disturbances, which is assumed to comprise white noise processes.

A balance needs to be made between the number of lag periods and the degrees of freedom. As a general guide, the number of lags chosen should be based on the lowest value of the Schwartz Criterion (SC) and Akaike Information Criterion (AIC). The formulae to explain the SC and AIC are as follows:

$$
\begin{aligned}
& \mathrm{AIC}=-2 l / n+2 k / n \\
& \mathrm{SC}=-2 l / n+k \log n / n
\end{aligned}
$$

where $\mathrm{k}=\mathrm{m}(\mathrm{qd}+\mathrm{pm})$ represents the number of parameters which need to be estimated, and $\mathrm{n}$ is the sample size which satisfies the following:-

$$
l=-2 \frac{n m}{2}(1+\log 2 \pi)-\frac{n}{2} \log \left[\operatorname{det}\left(\sum_{t} \check{\varepsilon} t \check{\varepsilon}^{\prime} t / n\right)\right]
$$

In order to ensure estimation accuracy, the number of variables and the lag periods were considered carefully in order to enable us to produce more robust estimates for purposes of achieving the research objectives.

\subsection{Toda-Yamamoto Augmented Vector Autoregression (VAR)}

A recent method proposed by Toda and Yamamoto (1995) is complementary to the Sims, Stock, and Watson (1990) technique as it allows for causal inference based on augmented VAR with integrated and cointegrated processes. The method is useful because it bypasses the need for potentially biased pre-tests for unit roots and cointegration common to other formulations.

The Toda-Yamamoto (1995) procedure uses a modified Wald (MWALD) test to test restriction on the parameters of the VAR $(\mathrm{k})$ model. The test has an asymptotic 
chi-squared distribution with $\mathrm{k}$ degrees of freedom in the limit when a VAR [k + $\mathrm{d}(\max )]$ is estimated (where $d(\max )$ is the maximal order of integration for the series in the system).

\subsection{Granger Causality Test}

In order to test the information transmission dynamics of the Islamic equity style indices and the macroeconomic variables, Granger's (1969) tests were used. This test was performed in a bivariate framework, where if variable $x$ Granger-causes variable $y$, the mean square error (MSE) of a forecast of $y$ based on the prior values of both variable $x$ and $y$ should be lower than the MSE of the forecast, which only uses the past value of $y$. Granger causality is further explained in Equation 7:

$$
\Delta y_{t}=\alpha+\sum_{i=1}^{p} \beta_{i} \Delta y_{t-1+} \sum_{i=1}^{p} \beta_{i} \Delta x_{t-1}+\varepsilon_{t}
$$

and testing the joint hypothesis:

$\mathrm{H}_{0}: \gamma_{1}=\gamma_{2}=\ldots . .=\gamma_{\mathrm{p}}=0$

$\mathrm{H}_{1}$ : At least one of the $\gamma_{1}$ is not equal to zero

The asymptotic chi-square test will then determine the Granger causality between variables $x$ and $y$. If the asymptotic chi-square test rejects $\mathrm{H}_{0}$, then shortrun dynamics exist from variable $x$ to variable $y$. Furthermore, if the test statistic is significant, it could therefore be argued that variable $x$ has predictive value for forecasting movement in variable $y$.

Furthermore, the joint significance of the lagged independent variables can be tested using F-statistics (the null hypothesis is $\mathrm{H}_{0}: \beta_{\mathrm{j}}=\alpha_{1}=0$ in Eq. 1 and $\mathrm{H}_{0}: \beta \mathrm{i}=\alpha_{2}=$ 0 in Equation 8).

The test statistics are as shown below:

$$
F=\frac{\left(R S S_{R}-R S S_{u}\right) / p}{R S S_{u} /(n-k p-1)} \sim F \text { Distribution }
$$

Which is computed where $\mathrm{RSS}_{\mathrm{R}}$ is the residual sum square of the restricted model, while $\mathrm{RSS}_{\mathrm{u}}$ is the residual sum square of the unrestricted model; $n$ represents the number of observations and $p$ is the order of the VAR model. Based

on the hypotheses, $\mathrm{H}_{o}$ is rejected if $\mathrm{F}>\mathrm{F}_{\alpha, n-k p-1}$. The possible outcomes of the Granger Causality test are unidirectional causality, bidirectional causality or no causality.

\section{RESULTS AND ANALYSIS}

\subsection{Descriptive Statistics}

Table 2 shows the descriptive statistics of all the series, which indicate that the Bursa Malaysia Industrial Index has the highest standard deviation compared to the other indices. In contrast, the LEI index has the lowest level of standard 
deviation. The LV index has a higher level of standard deviation at 52.3, compared to the LG index at 39.1. This indicates that the LV is riskier than the LG.

Table 2.

Descriptive Statistics

\begin{tabular}{lcccccc}
\hline Variable & Mean & Median & Maximum & Minimum & Std. Dev. & Observations \\
\hline LG & 175.4091 & 182.6197 & 226.3224 & 94.62048 & 39.08 & 132 \\
LV & 176.3506 & 159.8566 & 256.5310 & 88.75946 & 52.30 & 132 \\
LEI & 111.6140 & 112.0320 & 118.9426 & 101.2778 & 5.22 & 132 \\
CEI & 114.3042 & 112.8098 & 130.0309 & 98.19419 & 7.82 & 132 \\
KLCI & 1474.037 & 1548.415 & 1879.240 & 864.4900 & 280.69 & 132 \\
Industrial & 2799.573 & 2829.471 & 3347.825 & 1852.331 & 367.58 & 132 \\
\hline
\end{tabular}

Notes: LG denotes Large Growth; LV denotes Large Value LEI denotes Leading Economic Indicator; CEI denotes Coincident Economic Indicator; KLCI denotes Kuala Lumpur Composite Index; and Industrial denotes the Bursa Malaysia Industrial Index.

\subsection{Unit Root Test Results}

All the series were transformed into the natural logarithm form before the unit root test was conducted to avoid the possibility of nonstationarity in the variance of the series. Phillips-Perron (PP) and KPSS tests were conducted on the logarithmic series of the respective variables of Large Growth Islamic Equity Style Indices ( $L n L G)$; Large Value Islamic Equity Style Indices $(\operatorname{LnLV})$; Leading Economic Indicator (LnLEI); Coincident Economic Indicator (LnCEI); Kuala Lumpur Composite Index (LnKLCI); and Bursa Malaysia Industrial Index (LnIndustrial).

As shown in Table 3, both the PP and KPSS tests show that LnLG, LnLV, LnLEI, LnCEI and LnKLCI become stationary after taking the first difference. As for Industrial, the PP test shows that it is stationary at level, while for the KPSS test, LnIndustrial does not reject the null hypothesis, hence it is stationary at level. Therefore, we conclude that LnIndustrial is $\mathrm{I}(0)$ processes, while LnLG, LnLV, LnLEI, LnCEI, and LnKLCI are I(1) processes. Subsequently, we take the first difference for LnLG, LnLV, LnLEI, LnCEI and LnKLCI in the VAR model.

Table 3.

Unit Root and Stationary Test Results

\begin{tabular}{lcccc}
\hline \multirow{2}{*}{ Series } & \multicolumn{2}{c}{ PP Test } & \multicolumn{2}{c}{ KPSS test } \\
\cline { 2 - 5 } & Level & First difference & Level & First difference \\
\hline LnLG & $-2.31(5)$ & $-10.13(4)^{* * *}$ & $1.26(9)^{* *}$ & $0.21(5)$ \\
LnLV & $-1.75(4)$ & $-10.32(3)^{* * *}$ & $1.30(9)^{* *}$ & $0.10(4)$ \\
LnLEI & $-2.64(6)$ & $-13.72(5)^{* * *}$ & $0.15(6)^{* *}$ & $0.07(6)$ \\
LnCEI & $-0.27(6)$ & $-12.84(6)^{* * *}$ & $1.25(9)^{* *}$ & $0.10(6)$ \\
LnKLCI & $-2.00(6)$ & $-9.77(5)^{* * *}$ & $1.09(9)^{* *}$ & $0.09(6)$ \\
LnIndustrial & $-3.55(4)^{* *}$ & & $0.05(8)$ \\
\hline Notes: *** and & &
\end{tabular}

Notes: ${ }^{* * *}$ and ${ }^{* *}$ denote statistical significance at the $1 \%$ and $5 \%$ levels respectively. 
Figures in parentheses are the optimal lag lengths chosen.

Ln denotes the series is transformed into the natural logarithm.

LG denotes Large Growth; LV denotes Large Value, LEI denotes Leading Economic Indicator; CEI denotes Coincident Economic Indicator; KLCI denotes Kuala Lumpur Composite Index; and Industrial denotes the Bursa Malaysia Industrial Index.

\subsection{Granger's Causality and Modified Wald Test Results}

We proceeded to form a vector autoregressive model (VAR) and conducted Granger's Causality test on it. The lag length criteria were checked, and the model shown to be at its optimal lag length six. Figure 1 shows that all the roots lie within the unit circle; therefore, the model is stable.

Table 4 shows the Granger Causality test results based on the VAR model. According to these, Figure 2 was produced. To ensure the validity of VAR (6), tests for autocorrelation and heteroscedasticity were conducted, which showed it was free from such problems. Therefore, the model is robust. Notably, as can be seen in Table 4, there is unidirectional causality from the Islamic large growth style index to LEI, a result which strongly supports Hypothesis 1. Furthermore, there is unidirectional causality from LG to KLCI and from LV to KLCI, meaning Hypothesis 2 is also well supported.

In the context of Malaysia, Shariah-compliant stocks are also linked to Government Linked Companies (GLCs) and Government-Linked Investment Companies (GLICs). These firms, with high PE, attract investors and therefore active market participation, which translates into extensive information within the market.

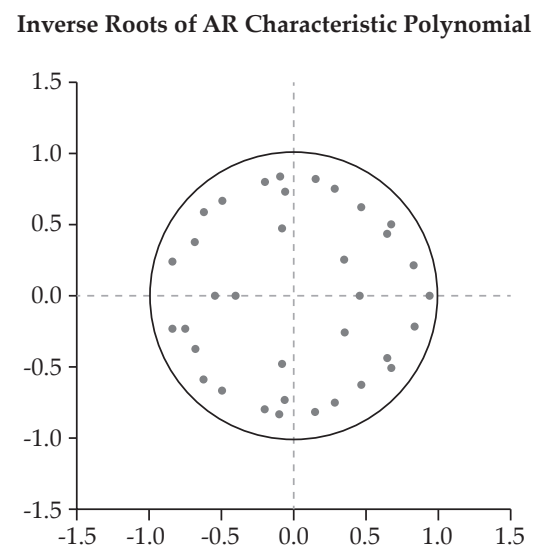

Figure 1.

Stability Test 
Table 4.

Granger Causality Test Results Based on the VAR Model

\begin{tabular}{lcccccc}
\hline \multirow{2}{*}{$\begin{array}{c}\text { Dependent } \\
\text { Variable }\end{array}$} & \multicolumn{6}{c}{ Independent Variables } \\
\cline { 2 - 7 }$\Delta$ LnLG & $\Delta$ LnLV & $\Delta$ LnLEI & $\Delta$ LnCEI & $\Delta$ LnKLCI & LnIndustrial \\
\hline \multirow{2}{*}{$\Delta$ LnLV } & 54.918 & 98.093 & 75.137 & 47.988 & 180.662 \\
& & $(0.4825)$ & $(0.1329)$ & $(0.2759)$ & $(0.5699)$ & $(0.0061)^{* * *}$ \\
$\Delta$ LnLEI & 53.829 & & 95.451 & 104.669 & 67.119 & 153.892 \\
& $(0.4957)$ & & $(0.1452)$ & $(0.1063)$ & $(0.3483)$ & $(0.0174)^{* *}$ \\
& 116.943 & 60.896 & & 44.512 & 146.537 & 125.473 \\
$\Delta$ LnCEI & $(0.0691)^{*}$ & $(0.4132)$ & & $(0.6159)$ & $(0.0231)^{* *}$ & $(0.0508)^{*}$ \\
& 55.173 & 96.333 & 241.325 & & 109.299 & 262.584 \\
$\Delta$ LnKLCI & $(0.4794)$ & $(0.1410)$ & $(0.0005)^{* * *}$ & & $(0.0906)^{*}$ & $(0.0002)^{* * *}$ \\
& 147.855 & 119.981 & 55.929 & 136.308 & & 82.870 \\
LnIndustrial & $(0.0220)^{* *}$ & $(0.0620)^{*}$ & $(0.4703)$ & $(0.0340)^{* *}$ & & $(0.2178)$ \\
& 84.277 & 72.484 & 112.480 & 120.745 & 80.968 & \\
\hline & $(0.2084)$ & $(0.2985)$ & $(0.0810)^{*}$ & $(0.0603)^{*}$ & $(0.2311)$ & \\
\hline
\end{tabular}

Note: ${ }^{* * *}$ and ${ }^{* * *}$ denote statistical significance at $10 \%, 5 \%$ and $1 \%$ levels respectively.

All estimates are asymptotic Granger Chi-squared statistics. The values in parentheses are p-values.

Ln denotes the series is transformed into the natural logarithm.

LG denotes Large Growth; LV denotes Large Value, LEI denotes Leading Economic Indicator; CEI denotes Coincident Economic Indicator, KLCI denotes Kuala Lumpur Composite Index; Industrial denotes Bursa Malaysia Industrial Index.

The same set of variables was estimated using the Toda and Yamamoto (1995) procedure. Based on the results in Table 5 which are summarised in Figure 3. Although the optimal lag length of the VAR model was six, a $(k+1=7)$ order VAR was estimated with restrictions placed on lagged terms up to the $k$ th lag.

The results provide information about the long-run causal relationships within the six indices. The results of the TY and VAR models are similar, except for bi-directional causality between LEI and Industrial, and unidirectional causality from KLCI to LEI. 
Table 5.

Toda-Yamamoto Modified Wald test results

\begin{tabular}{lcccccc}
\hline \multirow{2}{*}{$\begin{array}{c}\text { Dependent } \\
\text { Variable }\end{array}$} & \multicolumn{5}{c}{ Independent Variables } \\
\cline { 2 - 6 } & LnLG & LnLV & LnLEI & LnCEI & LnKLCI & LnIndustrial \\
\hline LnLG & & 27.483 & 86.547 & 73.134 & 57.094 & 224.832 \\
& & $(0.8397)$ & $(0.1939)$ & $(0.2928)$ & $(0.4565)$ & $(0.0010)^{* *}$ \\
LnLV & 24.435 & & 82.224 & 92.308 & 54.829 & 159.774 \\
& $(0.8747)$ & & $(0.2223)$ & $(0.1610)$ & $(0.4835)$ & $(0.0139)^{* *}$ \\
LnLEI & 115.700 & 58.647 & & 62.008 & 89.518 & 104.641 \\
& $(0.0723)^{* * *}$ & $(0.4385)$ & & $(0.1011)$ & $(0.1763)$ & $(0.1064)$ \\
LnCEI & 90.497 & 99.089 & 195.413 & & 32.206 & 124.984 \\
& $(0.1708)$ & $(0.1285)$ & $(0.0033)^{* *}$ & & $(0.7807)$ & $(0.0517)^{* * *}$ \\
LnKLCI & 180.188 & 122.147 & 16.318 & 111.248 & & 86.784 \\
& $(0.0062)^{* *}$ & $(0.0573)^{* * *}$ & $(0.9503)$ & $(0.0846)^{* * *}$ & & $(0.1925)$ \\
LnIndustrial & 65.836 & 50.122 & 53.122 & 91.800 & 73.308 & \\
& $(0.3611)$ & $(0.5423)$ & $(0.5044)$ & $(0.1637)$ & $(0.2913)$ & \\
\hline
\end{tabular}

Note: ${ }^{* *}$ and ${ }^{* * *}$ denote statistical significance at the $5 \%$ and $10 \%$ levels respectively.

The $[\mathrm{k}+\mathrm{d}(\max )]$ th order level VAR was estimated with $\mathrm{d}(\max )=1$, since the order of integration is 1 . Lag length selection of $\mathrm{k}=6$.

All estimates are asymptotic Wald statistics;

values in parentheses are p-values.

Ln denotes all series have been transformed into the natural logarithm.

LG denotes Large Growth; LV denotes Large Value, LEI denotes Leading Economic Indicator; CEI denotes Coincident Economic Indicator, KLCI denotes Kuala Lumpur Composite Index; Industrial denotes Bursa Malaysia Industrial Index.

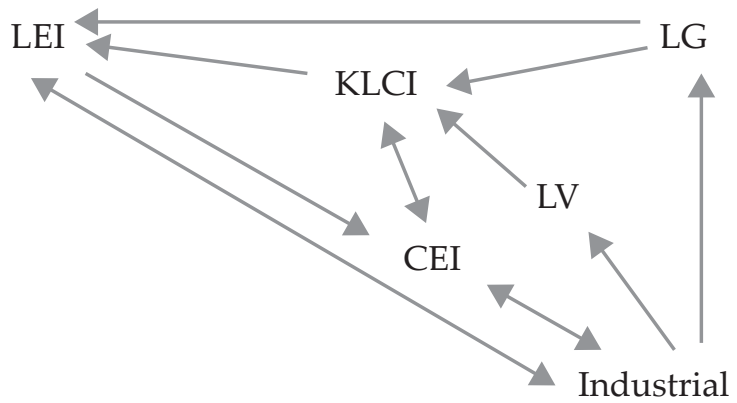

Figure 2.

Short-run VAR Model 


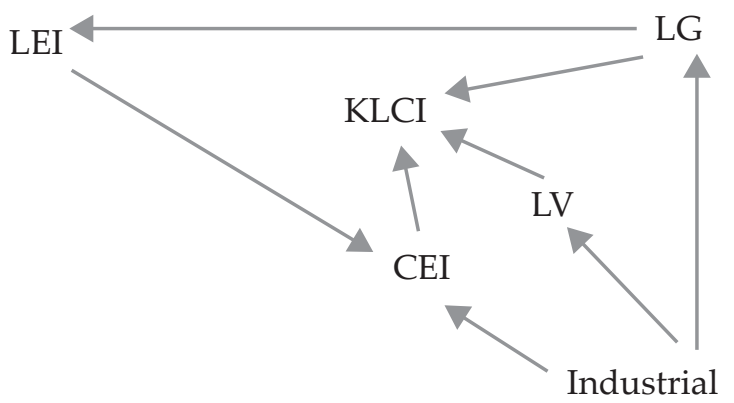

Figure 3.

Results of Augmented VAR model

In summary, the results underscore the fact that the newly constructed Islamic equity style indices have a short-run relationship with the macroeconomic indicator. In addition, the Granger causality test indicates that LG has more information content which is useful in predicting future economic conditions than LV. As such, there is unidirectional causality from LG to KLCI and from LG to LEI as compared to LV to KLCI. A similar finding was reported by Lau and Lee (2015).

\subsection{Further Analysis}

Further to Granger causality, we also examined the impulse response function and variance decomposition to examine the relevance between the equity style indices and economic indicators, and between the same indices and the stock market index.

As shown in Figure 4A, if there is one standard deviation shock in LG, LEI will decrease and return to equilibrium in roughly two months. However, the shock in KLCI seems to last longer, so if LEI decreases, it takes approximately four months to return to equilibrium (Figure $4 \mathrm{~B}$ ).

Next, KLCI reacts negatively to one standard deviation shock in LG, but becomes positive in three months, before declining. Overall, KLCI needs approximately seven months to return to equilibrium after a shock in LG (Figure 4C).

The effect is much longer than in LV, in which takes roughly three months for the KLCI to return to equilibrium (Figure 4D). The impulse response function further emphasises the role of the Islamic growth style index in transmitting information to other indicators. 

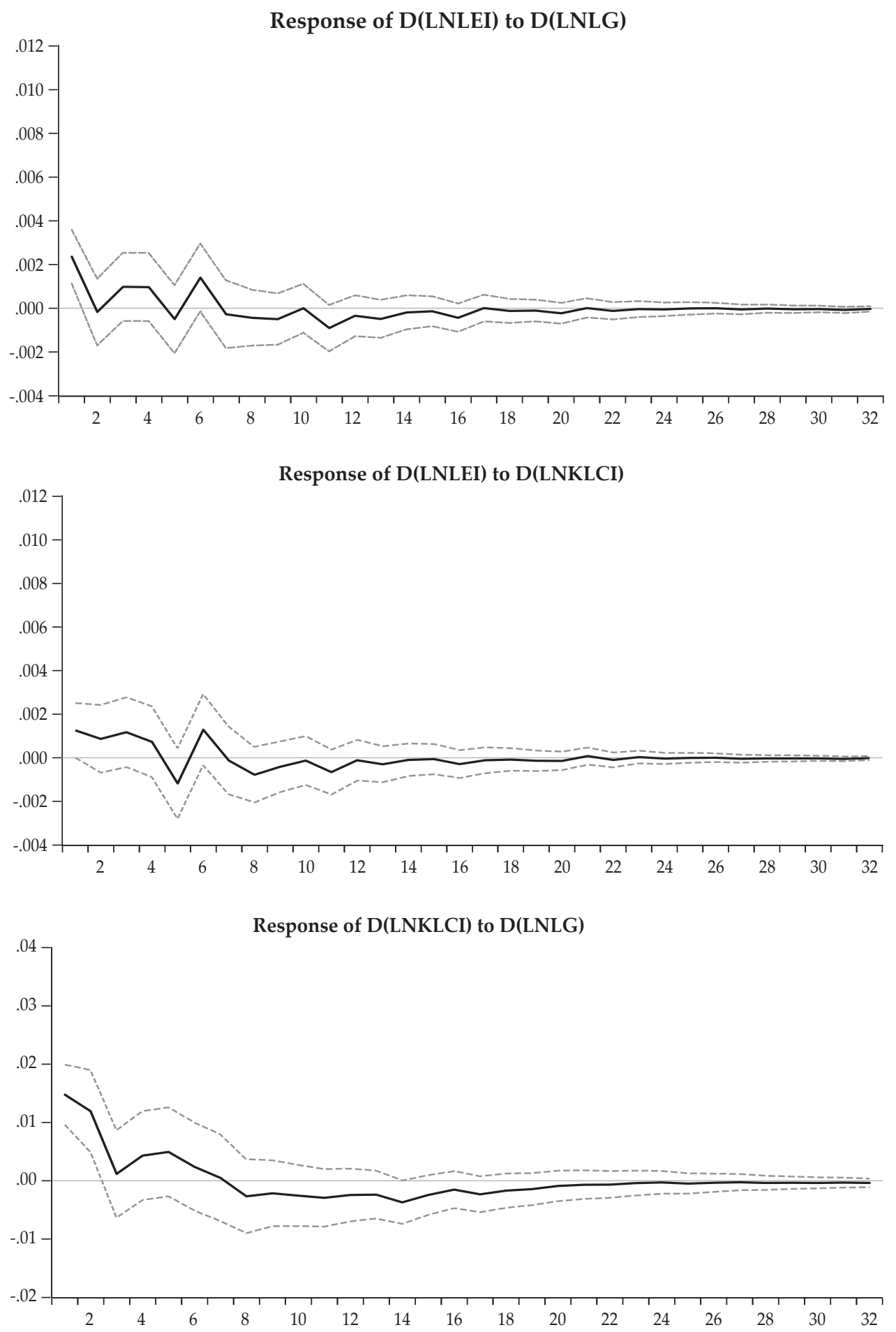

Figure 4.

Impulse Response 


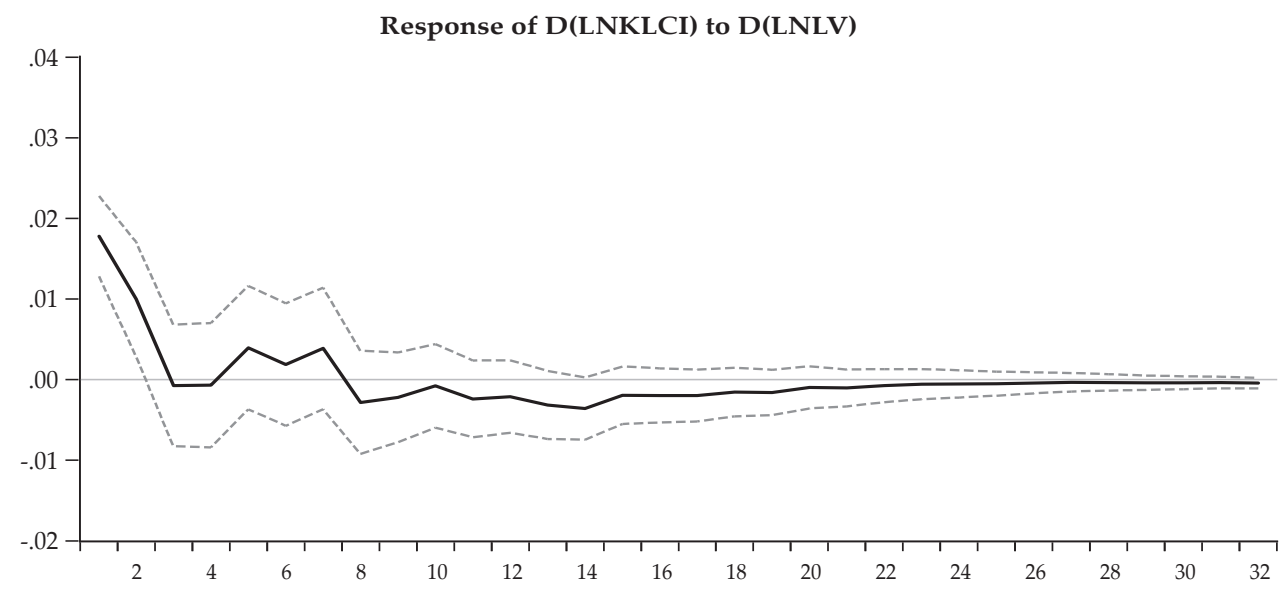

Figure 4.

Impulse Response (Continued)

Furthermore, the variance decomposition in Table 6 shows that LG plays the dominant role in explaining the variation in the LEI and KLCI. Moreover, the attribution of LG changes in explaining the variation in the LEI, and KLCI is strengthened with a more period-ahead forecast. The results from the impulse response and variance decomposition further support Hypotheses 1 and 2.

Table 6.

Variance Decomposition

\begin{tabular}{lcccccc}
\hline \multirow{2}{*}{ Period } & \multicolumn{5}{c}{ VDC of LnLEI } \\
\cline { 2 - 7 } & LnLEI & LnLG & LnLV & LnKLCI & LnCEI & LnIndustrial \\
\hline 4 & 8.141 .693 & 2.288 .669 & 3.718 .167 & 3.261 .417 & 3.418 .209 & 5.896 .609 \\
8 & 7.300 .487 & 6.039 .071 & 4.326 .503 & 6.167 .981 & 4.493 .541 & 5.968 .036 \\
12 & 7.146 .644 & 6.555 .404 & 4.202 .610 & 5.949 .680 & 6.114 .782 & 5.711 .088 \\
20 & 7.084 .624 & 6.792 .458 & 4.413 .525 & 5.925 .520 & 6.263 .700 & 5.758 .554 \\
24 & 7.084 .133 & 6.793 .231 & 4.412 .563 & 5.932 .558 & 6.267 .610 & 5.752 .706 \\
32 & 7.082 .292 & 6.802 .655 & 4.418 .169 & 5.931 .325 & 6.272 .909 & 5.752 .017 \\
\hline \multirow{2}{*}{ Period } & & & VDC of LnKLCI & & \\
\cline { 2 - 7 } 4 & LnLEI & LnLG & LnLV & LnKLCI & LnCEI & LnIndustrial \\
\hline 8 & 1.230 .487 & 1.745 .553 & 1.040 .334 & 4.287 .379 & 5.437 .531 & 1.152 .493 \\
12 & 1.481 .914 & 1.702 .170 & 1.030 .483 & 3.997 .859 & 6.913 .985 & 1.096 .175 \\
20 & 1.583 .649 & 1.730 .656 & 1.014 .987 & 3.892 .279 & 7.025 .747 & 1.075 .854 \\
24 & 1.665 .924 & 1.788 .537 & 1.026 .575 & 3.756 .371 & 6.917 .036 & 1.070 .888 \\
32 & 1.667 .977 & 1.788 .710 & 1.030 .480 & 3.750 .377 & 6.909 .627 & 1.071 .492 \\
\hline
\end{tabular}




\section{CONCLUSION AND RECOMMENDATIONS}

\subsection{Conclusion}

In summary, the VAR results based on the system of six series seem to show evidence that LV and LG have information content which precedes the macroeconomic variables in the short-run. This content is useful in predicting future economic conditions, as the LG index Granger causes LEI.

The results of the VAR tests also show evidence of the efficacy of the newly constructed Islamic equity style indices. In addition, they confirm the previous findings of Liew and Vassalou (1999) and Lau and Lee (2015). Consequently, it could be argued that investors, fund managers and regulators could use these indices for the purpose of asset allocation when designing Shariah-compliant portfolio investments. Knowing the direction of the economy will enable better timing and selection of stocks for the portfolio.

\subsection{Recommendations}

This type of asset allocation with economic content based on the LG and LV indices will deliver better results. Besides, the knowledge gained from the economic content will assist the construction of new leading economic indicators for better results in economic forecasting. As for future research, the LG and LV indices could be used in the factor model to identify the investment styles of fund managers and attribute their performance based on the equity style.

In addition, policymakers could refine the equity style indices and use them as new indicators to forecast the direction and turning points in the economy. They would also useful as an early warning signal tool for the business cycle.

\section{REFERENCES}

Abbes, S. M., Mostéfa, B., Seghir, G. M., \& Zakarya, G.Y. (2015). Causal Interactions between FDI, and Economic Growth: Evidence from Dynamic Panel CoIntegration. Procedia Economics and Finance, 23, 276 - 290.

Acikalin, S., Aktas, R., Unal, S. (2008). Relationships Between Stock Markets and Macroeconomic Variables: an Empirical Analysis of the Istanbul Stock Exchange. Investment Management and Financial Innovations, 5(1), 8-16.

Ahmed, P. (2001). Forecasting Correlations among Equity Mutual Funds. Journal of Banking and Finance, 25, 1187-1208.

Ahmed, R.R., Vveinhardt, J., Streimikiene, D., \& Fayyaz, M. (2017). Multivariate Granger Causality between Macro Variables and KSE 100 Index: Evidence from Johansen Cointegration and Toda \& Yamamoto Causality. Economic Research, 30(1), 1497-1521.

Ajmi, A., Hammoudeh, S., Nguyen, D., \& Sarafraziba, S. (2014). How Strong are the Causal Relationships between Islamic Share Markets and Conventional Financial Systems? Evidence from Linear and Nonlinear Tests. Journal of International Financial Markets, Institutions \& Money, 28, 213- 227.

Alam, M.J., Begum, I.A., Buysse, J., \& Huylenbroeck, G. (2012). Energy Consumption, Carbon Emissions and Economic Growth Nexus in Bangladesh: Co-integration and Dynamic Causality Analysis. Energy Policy, 45, 217-225. 
Albaity, M., \& Ahmad, R. (2008). Performance of Syariah and Composite Indices: Evidence from Bursa Malaysia. Asian Academy of Management Journal of Accounting and Finance, 4(1), 23-43.

Awokuse, T. O. (2003). Is the Export-led Growth Hypothesis Valid for Canada? Canadian Journal of Economics/Revue Canadienne d'Économique, 36, 126-136. doi: 10.1111/1540-5982.00006

Banerjee, A., \& Marcellino, M. (2009). Factor-augmented Error Correction Models. In: J. Castle \& N. Shepard (Eds.), The Methodology and Practice of Econometrics a Festschrift for David Hendry. 227-254. Oxford: Oxford University Press.

Bank Negara Malaysia (Online). Retrieved 4 November 2010, from http://www. bnm.gov.my.

Burkart, O., \& Coudert., V. (2002). Leading Indicators of Currency Crises for Emerging Countries. Emerging Markets Review, 3, 107-133.

Burns, A.F., \& Mitchell, W.C. (1945). Measuring Business Cycles. National Bureau of Economic Research, NY.

Camilleri, S.J., Scicluna, N., \& Bai, Y. (2019). Do Stock Markets Lead or Lag Macroeconomic Variables? Evidence from Select European countries. North American Journal of Economics and Finance, 48, 170-186.

Chen, N., Roll, R., \& Ross, S. A. (1986). Economic Forces and the Stock Market. Journal of Business, 59, 383-403.

Chen, S.W. (2007). Measuring Business Cycle Turning Points in Japan with the Markov Switching Panel Model. Mathematics and Computers in Simulation, 76, 263-270.

Click, R., \& Plummer, M. (2005). Stock Market Integration in ASEAN after the Asian Financial Crisis. Journal of Asian Economics, 16, 5-28.

Datastream (2011). Thomson Reuters Datastream. [Online]. Retrieved November 2011, from Subscription Service..

De Bondt, W. F. M., \& Thaler, R. M. (1985). Does the Stock Market Overreact? Journal of Finance, 40(3), 793-805.

De la Grandville, O. (2001). Bond Pricing and Portfolio Analysis. MIT Press, 248252.

Department of Statistics Malaysia. (2017). Malaysia Economic Indicators: Leading, Coincident \& Lagging Indices. Government Printers, Kuala Lumpur, various issues from $2000-2017$.

Diamandis, P. (2009). International Stock Market Linkages: Evidence from Latin America. Global Finance Journal, 20, 13-30.

Diebold, F. X., \& Rudebusch, G.D. (1991). Forecasting Output with the Composite Leading Index: A Real-time analysis. Journal of the American Statistical Association, 86(415), 603-610.

Diebold, F. X., Gunther, T., \& Tay, A. (1998). Evaluating Density Forecasts with Applications to Financial Risk Management. International Economic Review, 39, 863-883.

Dolado. J., \& Liitkepohl, H. (1996). Making Wald Tests Work for Cointegrated VAR System. Econometric Reviews, 15, 369-386.

Elliott, G., Rothenberg, T.J, \& Stock J.H. (1996). Efficient Tests for an Autoregressive Unit Root. Econometrica, 64(4), 813-836. 
Engle, R. F., \& Granger, C. W. J. (1987). Cointegration and Error Correction: Representation, Estimation, and Testing. Econometrica, 55, 251-276.

Fabozzi, F. (1998) Handbook of Portfolio Management. New Hope, Pennsylvania: Frank J. Fabozzi Associates.

Fama, E.F. (1970). Efficient Capital Markets: A Review of Theory and Empirical Work. Journal of Finance, 25, 383-417.

Fama, E. F. (1981). Stock Returns, Real Activity, Inflation and Money. The American Economic Review, 71(4), 45-565.

Fama, E.F., \& French, K.R. (1992). The Cross-Section of Expected Stock Returns. Journal of Finance, 47(2), 427-465.

Ferrara, L., Marcellino, M., \& Mogliani, M. (2015). Macroeconomic Forecasting during the Great Recession: The Return of Non-linearity? International Journal of Forecasting, 31, 664-679.

Filardo, A. (1994). Business-Cycle Phases and Their Transitional Dynamics. Journal of Business E Economic Statistics, 12(3), 299-308.

Frankel, J., \& Saravelos, G. (2012). Can Leading Indicators Assess Country Vulnerability? Evidence from the 2008-09 Global Financial Crisis. Journal of International Economics, 87, 216-231.

Gan, C., Lee, M., Yong, H.H.A., \& Zhang, J. (2006). Macroeconomic Variables and Stock Market Interactions: New Zealand Evidence. Investment Management and Financial Innovations, 3(4), 89-101.

Gaudreault, C., Lamy, R., \& Liu, Y. (2003). New Coincident, Leading and Recession Indexes for the Canadian Economy: An Application of the Stock and Watson Methodology. Working Paper 2003-12, Department of Finance, Canada.

Giuliodori, D., \& Rodriguez, A. (2015). Analysis of the Stainless Steel Market in the EU, China and US using Cointegration and VECM. Resources Policy, 44, 12-24.

Granger, C.W.J. (1969). Investigating Causal Relations by Econometric Models and Cross-Spectral Methods. Econometrica, 37, 424-438.

Gupta, R., \& Guidi, F. (2012). Cointegration Relationship and Time-varying Comovements among Indian and Asian Developed Stock Markets. International Review of Financial Analysis, 21, 10-22.

Hallam, D., \& Zanoli, R. (1993). Error-correction Models and Agricultural Supply Response. European Review of Agricultural Economics, 20(2), 155-166. ISSN 14679353. doi: 10.1093/erae/20.2.151.

Hamilton, J.D., \& Perezquiros, G. (1996). What Do the Leading Indicators Lead? The Journal of Business, 69(1), 27-49.

Hashemzadeh, N., \& Taylor, P. (1988). Stock Prices, Money Supply, and Interest Rates: The Question of Causality. Applied Economics, 20(12), 1603-1611.

Hussin, M.Y.M., Muhammad, F., Hussin, M.F.A., \& Razak, A.A. (2012). The Relationship between Oil Price, Exchange Rate and Islamic Stock Market in Malaysia. Research Journal of Finance and Accounting, 3(5), 83-92.

Hussin, M.Y.M., Muhammad, F., Awang, S.A. Marwan, N.F., \& Razak, A.A. (2013). The Dynamic Interaction between Islamic Stock Market and Strategic Commodities. Journal of Islamic Economics, Banking and Finance, 9(3), 54-68.

Ibrahim, M.H., \& Aziz, H. (2003). Macroeconomic Variables and the Malaysian Equity Market. Journal of Economic Studies, 30(1), 6-27. 
Jan Babecký, J., Havránek, T., Mat, J., Rusnák, M., Smídková, K., \& Vasícek, B. (2013). Leading Indicators of Crisis Incidence: Evidence from Developed Countries. Journal of International Money and Finance, 35, 1-19.

Johansen, S., \& Juselius, K. (1990). Maximum Likelihood Estimation and Inference on Cointegration with Application to the Demand for Money. Oxford Bulletin of Economics and Statistics, 52, 169-221.

Johansen, S., \& Juselius, K. (1992). Testing Structural Hypotheses in a Multivariate Cointegration Analysis of the PPP and the UIP for the UK. Journal of Econometrics,. 53, 211-244.

Johansen, S. (1988). Statistical Analysis of Cointegration Vectors. Journal of Economic Dynamics \& Control, 12, 231-254.

Johansen, S., \& Nielsen, B. (1993). Asymptotics for Co-integration Rank Test in the Presence of Intervention Dummies: Manual for the Simulation Program DisCo, Reprint. The University of Copenhagen.

Juselius, K. (1994). On the Duality Between Long-Run Relations and Common Trends in the I(1) and the I(2) case: An Application to the Aggregate Money Holdings. Econometric Reviews, 13, 151-178.

Khalichi, A. E., Humayun, K. S., Arouri, M., \& Teulon, F. (2014). Are Islamic Indices More Efficient than their Conventional Counterparts? Evidence from Major Global Families. The Journal of Applied Business Research, 30(4), 1137-1150.

Khandelwal, R. (2018). An Econometric Analysis of Linkages between Macroeconomic Variables and Stock Markets: Evidence from Asian Emerging Markets. International Journal of Financial Management, 8(1), 27-35.

Kumar, K.K., \& Sahu. B. (2017). Dynamic Linkages between Macroeconomic Factors and Islamic Stock Indices in a Non-Islamic country India. Journal of Developing Areas, 51(1), 193-205.

Kwoon, C.S., \& Shin, T.S. (1999). Cointegration and Causality between Macroeconomic Variables and Stock Market Returns. Global Finance Journal, 10(1), 71-81.

Lau, W.Y., \& Lee, C. (2015). Testing the Efficacy of Information Transmission: Is Equity Style Index Better than Stock Market Index? Economics and Management, 18(3), 4-17.

Lau, W.Y. (2005). How Persistent is Equity Style Performance Among Malaysian Fund Managers? Osaka Economic Papers, 55(3), 64-82.

Liew, J., \&Vassalou, M. (1999). Can Book-to-Market, Size and Momentum be Risk Factors that Predict Economic Growth? Journal of Financial Economics, 57, 221245.

Lin, T., \& Lin., Z.H. (2011). Are Stock and Real Estate Markets Integrated? An Empirical Study of Six Asian Economies. Pacific-Basin Finance Journal, 19, 571585.

Lo, A.W., \& Mackinlay, AC (1987). Stock Market Prices Do Not Follow Random Walks: Evidence from a Simple Specification Test. Working paper 28-87, Rodney L. White Centre, Wharton School, University of Pennsylvania.

Maysami, R. C., \& Sim, H. H. (2002). Macroeconomics Variables and their Relationship with Stock Returns: Error Correction Evidence from Hong Kong and Singapore. The Asian Economic Review, 44(1), 69-85. 
McNown, R., \& Seip, K.L. (2011). Periods and Structural Breaks in US Economic History 1959-2007. Journal of Policy Modeling, 33, 169-182.

Megna, R., \& Xu, Q. (2003). Forecasting the New York State Economy: The coincident and Leading Indicators Approach. International Journal of Forecasting, 19, 701713.

Mookerjee, R., \& Yu, Q. (1997). Macroeconomic Variables and Stock Prices in a Small Open Economy. The Case of Singapore. Pacific-Basin Finance Journal, 5, 377-388.

Mosconi, R., \& Giannini, X. (1992). Non-causality in Cointegrated Systems: Representation Estimation and Testing. Oxford Bulletin of Economics and Statistics, 54(3), 399-417.

Obben, J. (1998). The Demand for Money in Brunei. Asian Economic Journal, 12(2), 109-121. ISSN 1467-8381. doi: 10.1111/1467-8381.00055.

Qin, D., Cagas, M.A., Ducanes, G., Magtibay-Ramos, N., \& Quising, P. (2008). Automatic Leading Indicators Versus Macro-econometric Structural Models: A Comparison of Inflation and GDP Growth Forecasting. International Journal of Forecasting, 24, 399-413.

Semra, K., \& Ayhan, K. (2003). Investigating Causal Relations among Stock Market and Macroeconomic Variables: Evidence from Turkey. International Journal of Economic Perspectives, 4(3), 501-507.

Shaharuddin, S. S., Lau, W.Y., \& Ahmad, R. (2017a). Constructing FamaFrench Factors from Style Indices: Evidence from the Islamic Equity Market, Emerging Markets Finance, and Trade, 53(7), 1563-1572. doi: 10.1080/1540496X.2016.1278529.

Shaharuddin, S. S., Lau, W.Y., \& Ahmad, R. (2017b). New Islamic Equity Style Indices: Constructing and Testing the Efficacy of Information Transmission. Cogent Economics and Finance, 5, 1-19. doi: 10.1080/23322039.2017.1363355

Shaharuddin, S. S., Lau, W.Y., \& Yip, T.M. (2017). Dynamic Linkages between Newly Developed Islamic Equity Style Indices: Is Growth Style more Influential than Value Style? Capital Market Review, 27(2), 49-64.

Simkins, S. (1995). Forecasting with Vector Autoregressive (VAR) Models Subject to Business Cycle Restrictions. International Journal of Forecasting, 11, 569-583.

Sims, C. (1980). Macroeconomics and Reality. Econometrica, 48(1), 1-48.

Spierdijk, L., \& Umar., Z. (2014). Stocks for the Long Run? Evidence from Emerging Markets. Journal of International Money and Finance, 47, 217-238.

Stock, J.H., \& Watson, M.W. (1989). New Indexes of Coincident and Leading Economic Indicators. NBER Macroeconomics Annual, 4, 351-409.

Sustainability Indicators, 101. (2010). Retrieved from http:// www. sustainablemeasures.com/node/92.

Tan L.Y., \& Lau, W.Y. (2013). Does Equity Style Index Play a Role in Transmitting Economic Information? Evidence from Selected Asia-Pacific Countries. In: M.N Norashidah (Ed), Readings on Applied Economics Issues. McGraw-Hill, ISBN 978-967-5771-89-7.

Toda, H.Y., \& Yamamoto (1995) Statistical Inference in Vector Autoregressions with Possibly Integrated processes. Journal of Econometrics, 66, 225-250.

Vassalou, M. (2003). News Related to Future GDP Growth as a Risk Factor in Equity Returns. Journal of Financial Economics, 68, 47-73. 
Wahyudi, I., \& Sani. GA, (2014). Interdependence Between the Islamic Capital Market and Money Market: Evidence from Indonesia. Borsa Istanbul Review, $14,32-47$.

Yahya, M., Muhammad, F., Awang, S.A., \& Ibrahim, M.F. (2012). Islamic Stock Market and Macroeconomic Variables: A Comparative Analysis. Journal of Contemporary Issues and Thought, 2, 41-56.

Zare, R., \&Azali, M. (2014). The Association Between Aggregated and Disaggregated Stock Prices with Monetary Policy Using Asymmetric Cointegration and Error-correction Modelling Approaches. Review of Development Finance Review of Development Finance, 5, 64-69. 
This page is intentionally left blank 